\title{
コーンカロリーメータ試験装置と着火性試験装置における材料表面の熱伝達 SPECIMEN SURFACE HEAT TRANSFER IN CONE CALORIMETER AND IGNITABILITY TEST APPARATUS
}

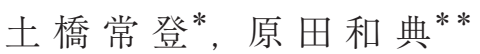 \\ Tsuneto TSUCHIHASHI and Kazunori HARADA
}

\begin{abstract}
To investigate the specimen's surface heat balance of the ISO 5660 cone calorimeter (CCM) and ISO 5657 ignitability test apparatus, galvanized thin steel plate $(0.27 \mathrm{~mm})$ was heated. CCM tests were carried out in horizontal and vertical orientations. The steady state surface temperatures were measured for heating intensities up to $60 \mathrm{~kW} / \mathrm{m}^{2}$. The corresponding surface temperatures were up to $720^{\circ} \mathrm{C}$. The specimen's surface heat balance was estimated by measured surface temperatures. In all the results, re-radiation by surface dominated the heat loss. Convection and conduction heat loss are relatively small. In comparison of horizontal and vertical CCM results, there was no obvious difference if the heating intensity is below $40 \mathrm{~kW} / \mathrm{m}^{2}$. Above $40 \mathrm{~kW} / \mathrm{m}^{2}$, when the surface temperature is higher than $600^{\circ} \mathrm{C}$, the convection heat loss was larger in vertical orientation. In case of ignitability test apparatus, convection heat loss is smaller than horizontal CCM, but the conduction heat loss was about six times larger. The estimated convective heat transfer coefficient was around $0.013-0.015 \mathrm{~kW} /\left(\mathrm{m}^{2} \cdot \mathrm{K}\right)$ in CCM for the surface temperature range of 200 to $400^{\circ} \mathrm{C}$. Above $600^{\circ} \mathrm{C}$, the coefficient tends to increase in vertical CCM. On the other hand, the convective heat transfer coefficient in ignitability test apparatus is about $0.006 \mathrm{~kW} /\left(\mathrm{m}^{2} \cdot \mathrm{K}\right)$, which is about half to one third of the values in CCM.
\end{abstract}

Keywords : Cone Calorimeter, Ignitability test apparatus, Surface heat balance, Convective heat transfer coefficient コーンカロリーメータ，着火性試験装置，表面の熱収支，対流熱伝達率

\section{1. はじめに}

内装材料が放射熱により加熱されるときの着火時間は，ISO5657 に規定される着火性試験 ${ }^{1)}$ (以下, 単に着火性試験と呼ぶ) で測定さ れてきた。着火性試験は, 円錐形の電熱ヒータによって試験体表面を 加熱し,ガスバーナーの口火を用いて着火時間を測定するものである。 一方, 近年, 内装防火設計法 ${ }^{2)}$ への応用が検討されているコーンカロ リーメータ試験 ${ }^{3)}$ (以下, CCM 試験之呼ぶ) では, 着火性試験装置 と同様の形状の電熱ヒータを用いて材料の発熱性 (発熱速度の時刻歷) 等を測定するものであるが，材料の着火時間も測定される。ただし， 着火時間は試験体表面の熱伝達に影響を受け, 同じ材料を同じ加熱強 度で加熱した場合でも, 着火性試験装置と CCM 試験装置では異なる ことが知られている ${ }^{4), 5)}$ 。CCM 試験装置と着火性試験装置で測定し た着火時間の違いを考察できれば有用である。

CCM 試験と着火性試験における試験体の熱収支に影響を及ぼす要 因としては, 試験体裹面に設置する裹打ち材の違いが考えられる。裏 打ち材の断熱性が異なると試験体裏面への伝導による熱損失が変化 し, 試験体表面の温度上昇に影響する ${ }^{6)}$ 。

さらに, 試験体表面の対流熱伝達率が挙げられる。対流熱伝達率は 試験装置や試験体の大きさなどの測定条件に依存するため, 試験装置 ごとに調べておく必要がある。特に CCM 試験では, 試験体を水平ま
たは鉛直に設置することが可能なので, 試験体の設置方向による違い を確認しておく必要がある。例えば，材料の着火時間と水平火炎伝播 速度の測定に用いられる LIFT 試験 7)においては，種々の試験体を 用いた測定結果に基づき, 着火時間の分析においては対流熱伝達率を $15 \mathrm{~W} /\left(\mathrm{m}^{2} \cdot \mathrm{K}\right)$ と規定している。 $\mathrm{CCM}$ 試験では試験法としての対流熱 伝達率の規定はないが, 既往の研究によって試験体を水平に設置した ときの值がいくつか提案されている ${ }^{8)}{ }^{11}$ 。これらの研究では, 設定 したいくつかの加熱強度で定常状態となったときの試験体表面温度 を測定し, 材料表面の熱収支式に代入して対流熱伝達率を算出してい る。しかし, 研究者によって提案值は大きく異なっている。さらに, 試験体を鉛直に設置した場合の対流熱伝達率についてはあまり知ら れていない。

また，CCM 試験装置と着火性試験装置では，口火の機構が異なっ ている。CCM 試験装置では常時作動している電気スパーク, 着火性 試験装置では 4 秒に 1 回の割合で試験体表面に 1 秒間接触するガス バーナーの口火を用いている。口火の違いが着火時間に影響を及ぼす ことが考えられるが、基本的には着火時間は表面温度上昇の速さに支 配されると考えて、着火性試験と CCM 試験の裏打ち材の違いと, $\mathrm{CCM}$ 試験での試験体設置方向の違いが，試験体表面の熱収支に及ぼ す影響について調べることを本研究の目的とする。そのため, 亜鉛め
* 一般財団法人日本建築総合試験所

** 京都大学大学院工学研究科 教授 $\cdot$ 博士 (工学)
Fire Engineering Lab, Environment Dept., General Building Research Corporation of Japan Prof., Graduate School of Engineering, Kyoto Univ., Dr. Eng. 
つき鋼板を種々の加熱強度で加熱して定常状態となったときの試験 体表面温度を測定し, 材料表面の熱収支式から, 試験体表面での反射, 再放射, 対流, 伝導の各熱流の内訳を求め, 対流熱伝達率を推定した。

\section{2. 材料表面の熱収支}

\section{1 試験装置の相違点の整理}

$\mathrm{CCM}$ 試験装置と着火性試験装置の加熱部分の断面を図 1 に示す。 両装置とも円錐形の電熱ヒータを用いるが, 直径は CCM 試験装置で $197 \mathrm{~mm}$, 着火性試験装置で $224 \mathrm{~mm}$ であり, 着火性試験装置の方が 若干大きい。加熱強度の設定は, 試験体表面中央の位置に Schmidt-Boelter 型熱流束計を設置し, 熱流束の測定值が設定值とな るように電熱ヒータの温度を調整する。CCM 試験では熱流束計単独 で測定するのに対し, 着火性試験では試験体と同寸のセラミックボー ドに熱流束計表面が露出するように埋め込んで測定する点が異なる。 試験体は，CCM 試験では大きさ $100 \mathrm{~mm} \times 100 \mathrm{~mm}$ （有効加熱面 $94 \mathrm{~mm} \times 94 \mathrm{~mm})$ の試験体の加熱面以外をアルミ箔で包み, セラミッ クブランケットを裏打ちして総厚 $50 \mathrm{~mm}$ として試験体ホルダーに挿 入し, 試験体の上部からリテイナーフレームを被せる。その状態で試 験体表面と電熱ヒータのベースプレートの間の距離が $25 \mathrm{~mm}$ となる ように設置する。

着火性試験は，大きさ $165 \mathrm{~mm} \times 165 \mathrm{~mm}$ の試験体に厚さ $6 \mathrm{~mm}$ の 不燃性ボードを裏打ちして直径 $140 \mathrm{~mm}$ の穴（有効加熱面）をあけた アルミ䈃で包む。それをステンレス製の試験体トレーに載せ, 試験体 を固定するプレートと電熱ヒータのベースプレート間が $22 \mathrm{~mm}$ (試 験体表面からは $26 \mathrm{~mm})$ となるように設置する。裏打ち材は, ISO5657 において厚さ $(6 \mathrm{~mm})$, 密度 $\left(825_{ \pm 125} \mathrm{~kg} / \mathrm{m}^{3}\right)$ および熱慣性 $(9.0 \times$ $10^{4} \mathrm{~W}^{2} \mathrm{~s} / \mathrm{m}^{4} \mathrm{~K}^{2}$ ) が規定されているので、けい酸カルシウム板（JIS A 5430 ，密度 $800 \mathrm{~kg} / \mathrm{m}^{3}$ 品）を慣用的に用いている。

両者を比較すると, 電熱ヒータの大きさが違うため加熱の均一度と 加熱面近傍の気流性状が異なること, 裏打ち材が異なるため試験体内 部への熱伝導による裏面への熱損失が異なることを検討する必要が ある。

\section{2 試験体表面の熱収支の測定方法}

図 2 に示寸ように, 一定の放射熱を受けて温度が定常状態となった 後の試験体表面の熱収支は式(1)で表される。

$\dot{q}_{e}^{\prime \prime}=\dot{q}_{r e f}^{\prime \prime}+\dot{q}_{r a d}^{\prime \prime}+\dot{q}_{c v}^{\prime \prime}+\dot{q}_{c d}^{\prime \prime}$

ここで, 式(1)右辺の反射, 再放射, 対流, 伝導の各熱流は, 式(2)〜 (5)で与えられる。

$\dot{q}_{r e f}^{\prime \prime}=(1-\varepsilon) \dot{q}_{e}^{\prime \prime}$

$\dot{q}_{\text {rad }}^{\prime \prime}=\varepsilon \sigma\left(T_{s}^{4}-T_{\infty}^{4}\right)$

$\dot{q}_{c v}^{\prime \prime}=h_{c}\left(T_{s}-T_{\infty}\right)$

$\dot{q}_{c d}^{\prime \prime}=K\left(T_{s}-T_{\infty}\right)$

放射率が既知の試験体を使って表面温度を測定し，式(2)，（3)，（5） から反射, 再放射, 伝導の各熱流を求め, これらを式(1)に代入する と対流熱流を求めることができる。
試験体表面の放射率に関しては、既往の研究では 1 とするものが多 いが，今回の測定では試験体の放射率を別途測定し、放射率を表面温 度の関数として表した注 ${ }^{1)}$ 。

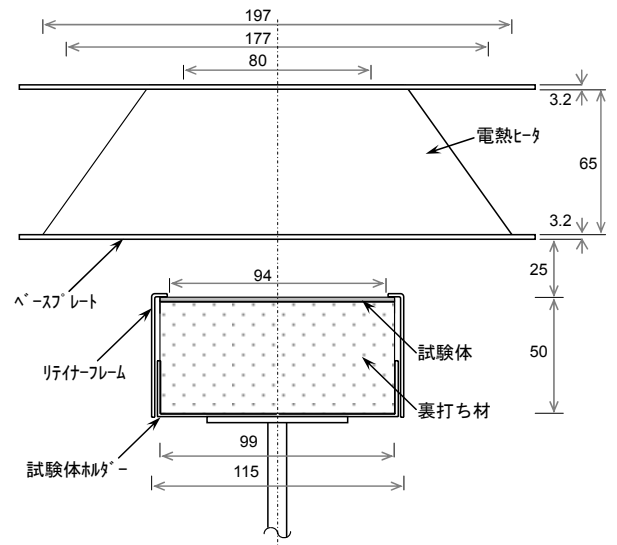

（CCM 試験装置）

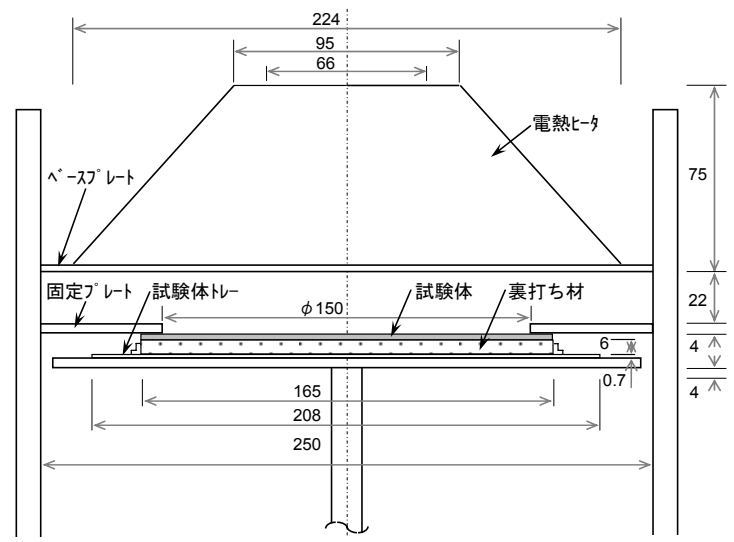

(着火性試験装置)

図 1 各試験装置の加熱部分（寸法単位：mm）

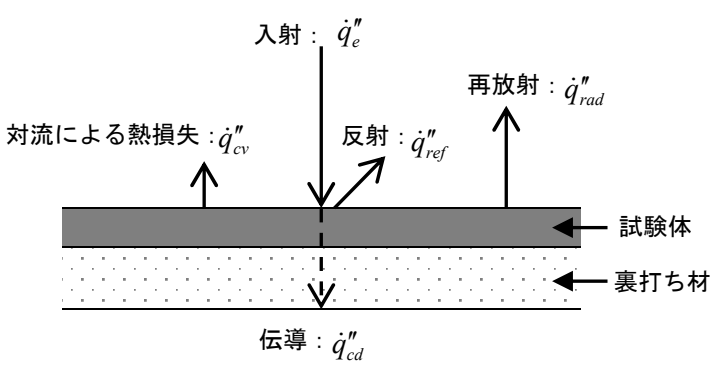

図 2 定常状態での材料表面の熱収支

3. 定常状態における試験体表面温度の測定

3.1 表面温度の測定方法

\subsubsection{CCM 試験}

(1) 実験条件

実験は ISO5660 の試験規格 ${ }^{3)}$ に従った。表面温度の測定状況を図 3 に示す。試験体の設置方向は, 水平設置および鉛直設置の 2 条件と した。このとき鉛直設置についても水平設置と同様の試験体構成とし, 試験体ホルダーおよびリテイナーフレームとも水平設置と同じもの 
を用いた。

2.1 節で述べたように，CCM 試験装置では，試験体と同じ場所に 熱流束計を単独で設置した状態で, 加熱強度が設定值となるように電 熱ヒータを較正しているが, 試験体設置時には試験体とヒータとの間 の放射熱の相互反射により入射熱流が若干増加する。そこで, 試験体 と同じ大きさのセラミックボードに熱流束計を埋め込んで測定する と, 熱流束計単独のときに比べ約 10\%増加した注2)。本研究では, 熱 流束計単独で測定した熱流束を「校正時の加熱強度」, 試験体設置時 に表面へ入射する熱流束を「試験体への加熱強度」と区別して扱う。 加熱強度の設定は, 校正時の加熱強度を用いた。最初 $5 \mathrm{~kW} / \mathrm{m}^{2}$ に 設定して最大 $60 \mathrm{~kW} / \mathrm{m}^{2}$ まで段階的に上げた後, $5 \mathrm{~kW} / \mathrm{m}^{2}$ まで段階的 に下げた。 $5 \sim 35 \mathrm{~kW} / \mathrm{m}^{2}$ の間は $5 \mathrm{~kW} / \mathrm{m}^{2}$ 間隔， $40 \sim 60 \mathrm{~kW} / \mathrm{m}^{2}$ の間 は $10 \mathrm{~kW} / \mathrm{m}^{2}$ 間隔とした。加熱強度の変更は, 設定した加熱強度で試 験体表面温度が安定してから 5 分以上経過した後に行った。

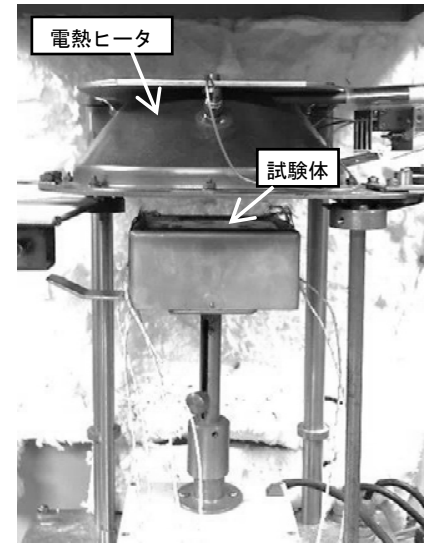

(水平設置)

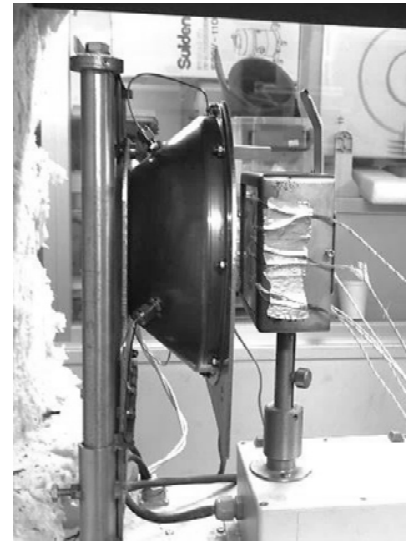

（鉛直設置）
図 3 CCM 試験装置による表面温度の測定状況

(2) 試験体

試験体は厚さ $0.27 \mathrm{~mm}$ の亜鉛めっき鋼板とし, 2.1 節の方法に従っ て設置した。試験体の各層の熱伝導率 $\lambda[\mathrm{W} /(\mathrm{m} \cdot \mathrm{K})]$ と厚さ $t[\mathrm{~mm}]$ を 図 4 に示す。試験体ホルダー裏面と下部空気との間の総合熱伝達率を 常用值の $20 \mathrm{~W} /\left(\mathrm{m}^{2} \cdot \mathrm{K}\right)$ と仮定して試験体の加熱面から裏面側空気ま での熱貫流率を求めると $1.82 \mathrm{~W} /\left(\mathrm{m}^{2} \cdot \mathrm{K}\right)$ となる。

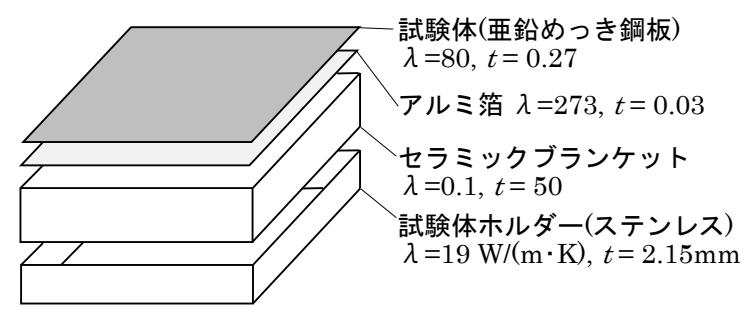

図 4 試験体の積層構成

\section{（3）表面温度測定}

図 5 に示すように試験体表面中心（測定点 1）と周囲（測定点 2〜 5）の合計 5 点に熱電対（タイプ $\mathrm{K}$, 素線径 $0.23 \mathrm{~mm}$ ）を電気溶接し た。また、試験体とヒータの隙間から図 3 とほぼ同じ方向から赤外線 カメラ (視野分解能: $3 \mathrm{~mm} / 1 \mathrm{~m}$, 測定レンジ $0 \sim 350^{\circ} \mathrm{C}$, 最小検知温
度差 $0.2^{\circ} \mathrm{C}$ ，測定精度 $\pm 2 \%$ ）により，試験体表面温度を測定した。こ のとき、赤外線力メラの放射率は 1.0 に設定した。撮影は各加熱強度 での熱電対の温度が一定となった後に行った。

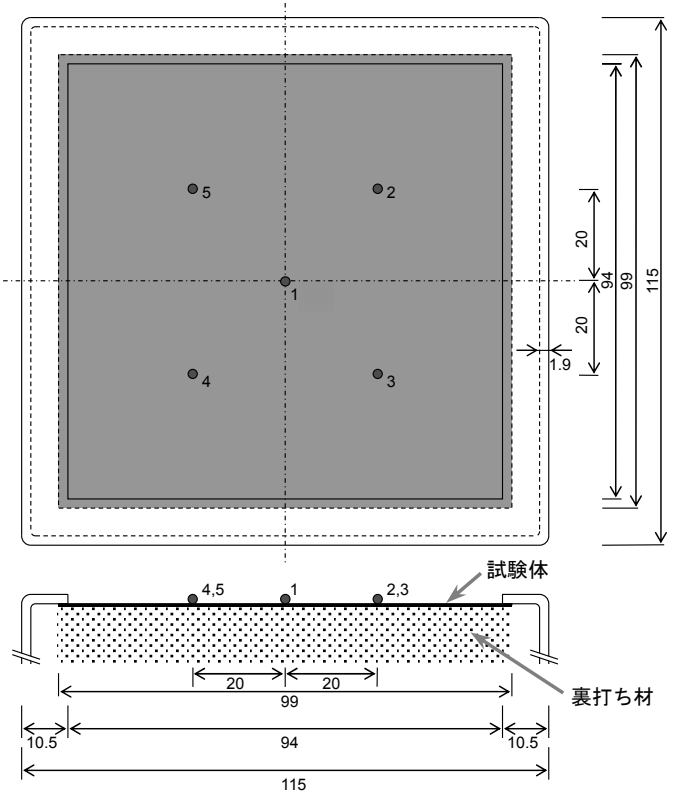

図 5 熱電対の設置位置（寸法単位 : $\mathrm{mm}$ )

\subsection{2 着火性試験}

\section{（1）実験条件}

実験は ISO5657 の試験規格 ${ }^{1)}$ に従った。表面温度の測定状況を図 6 に示す。試験体設置方向は水平のみとし，試験体への加熱強度を $\mathrm{CCM}$ 試験装置の校正時の加熱強度と同じ值になるように設定した。

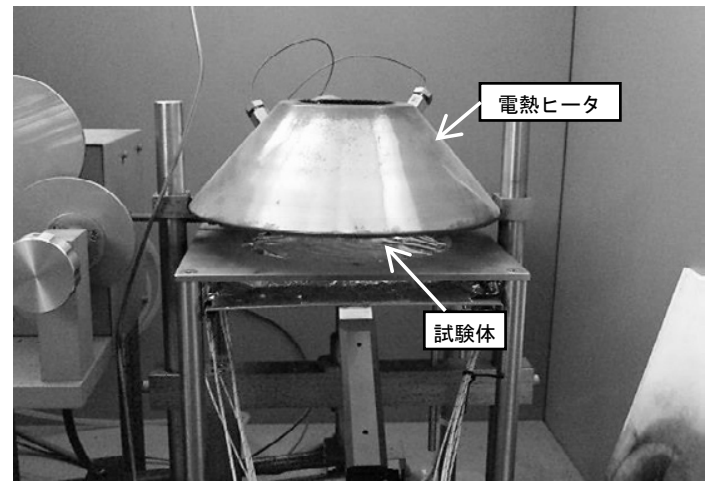

図 6 着火性試験装置による表面温度の測定状況

(2) 試験体

試験体は CCM 試験に用いたものと同一の亜鉛めっき鋼板とし, 試 験体は 2.1 節の方法に従って設置した。ただし, 熱電対を溶接した後, 加熱して表面を酸化させてから測定に用いた。試験体の各層の熱伝導 率と厚さを図 7 に示す。試験体トレー下部の固定板裏面と下部空気と の間の総合熱伝達率を常用值の $20 \mathrm{~W} /\left(\mathrm{m}^{2} \cdot \mathrm{K}\right)$ と仮定して，試験体の 加熱面から裏面側空気までの熱貫流率を求めると $11.9 \mathrm{~W} /\left(\mathrm{m}^{2} \cdot \mathrm{K}\right)$ と なる。 


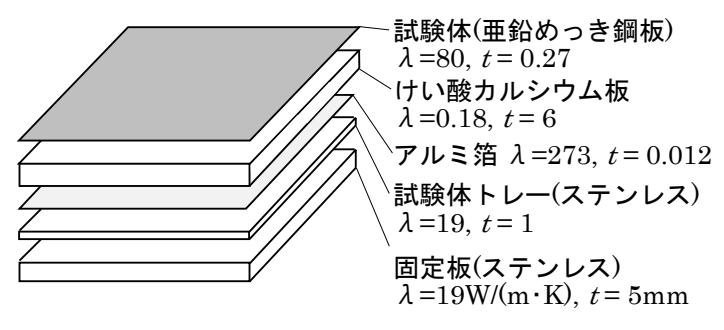

図 7 試験体の積層構成

(3) 表面温度測定

試験体の温度は, 図 8 に示寸位置の熱電対と, 図 6 とほぼ同じ方 向から赤外線カメラによって測定した。熱電対は CCM 試験と同位置 である試験体表面中心と周囲 4 点に加え, さらに端部 4 点（測定点 6 〜9）の温度を測定した。測定手順は CCM 試験と同じである。

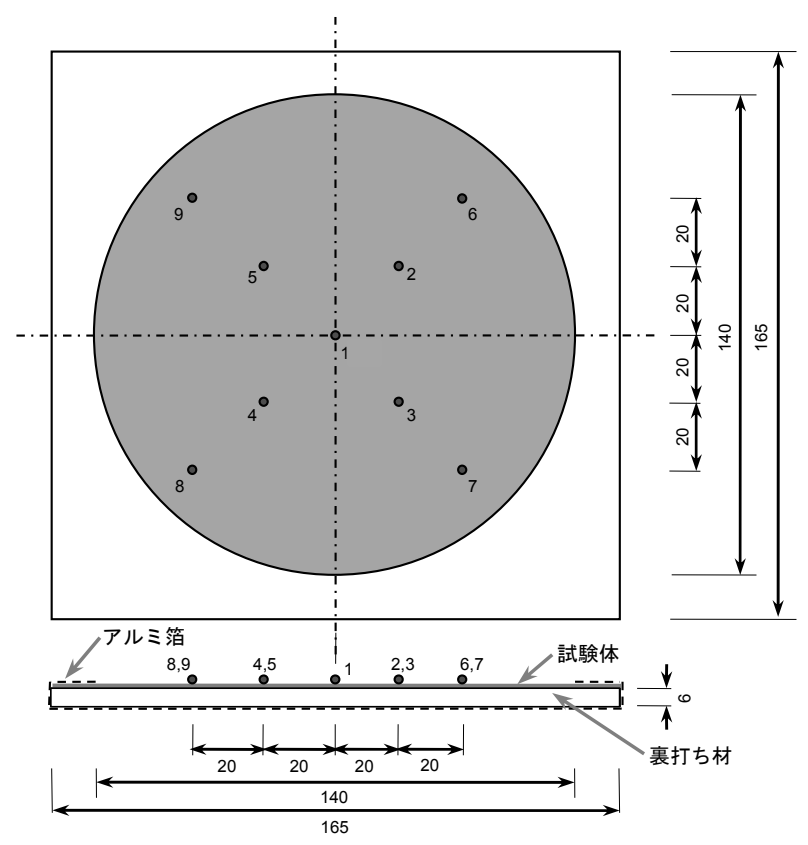

図 8 熱電対の設置位置（寸法単位：mm）

\section{2 表面温度の測定結果}

\subsubsection{CCM 試験の測定結果}

(1) 測定結果

試験体表面温度の測定結果について水平設置の場合を図 9 に, 鉛直 設置の場合を図 10 に示す。また, 試験体への加熱強度を破線で示す。

加熱強度の増加に応じて表面温度は上昇し, 水平設置で $43 \mathrm{~kW} / \mathrm{m}^{2}$ のとき $350{ }^{\circ} \mathrm{C}$ であった。鉛直設置ではこれよりもわずかに低い温度 となった。加熱強度を上げていく段階では試験体表面はまだ酸化して おらず，試験体表面の放射率は低い。そのため，赤外線カメラの測定 值は低い。

水平設置で $54 \mathrm{~kW} / \mathrm{m}^{2}$, 鉛直設置で $57 \mathrm{~kW} / \mathrm{m}^{2}$ に設定すると, 鋼板 表面が褐色に酸化し始め, 表面のほぼ全域が変色して表面温度が大き く上昇した後に安定した。最大の加熱強度での測定後に段階的に加熱 強度を下げていくと, 表面温度は徐々に低下したが, 酸化前の同じ加 熱強度での温度と比較すると酸化後の方がかなり高い。また, 赤外線
カメラで測定した表面温度は熱電対の值とほぼ等しく,酸化により放 射率が大きくなったと考えられる。ただし，図 10 において，赤外線 カメラの測定值が熱電対の測定值をわずかに上回っているものがあ るが, 試験体表面と赤外線カメラとの角度が浅いことによる測定誤差 が原因と考えられる。

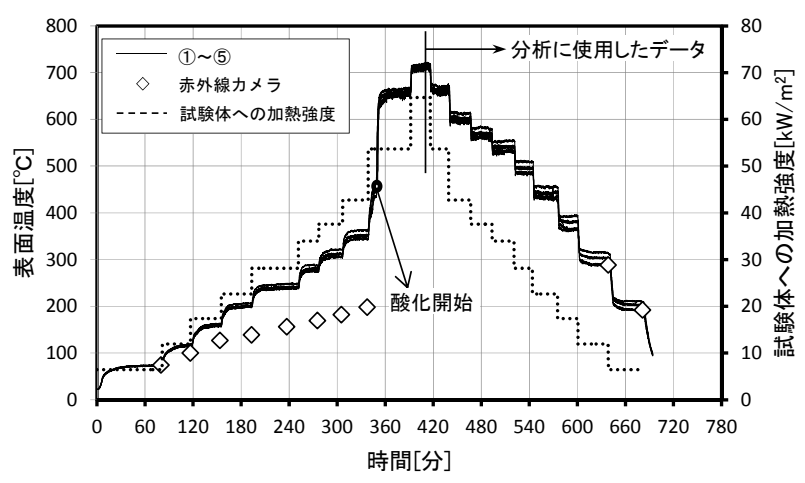

図 9 温度測定結果（水平設置）

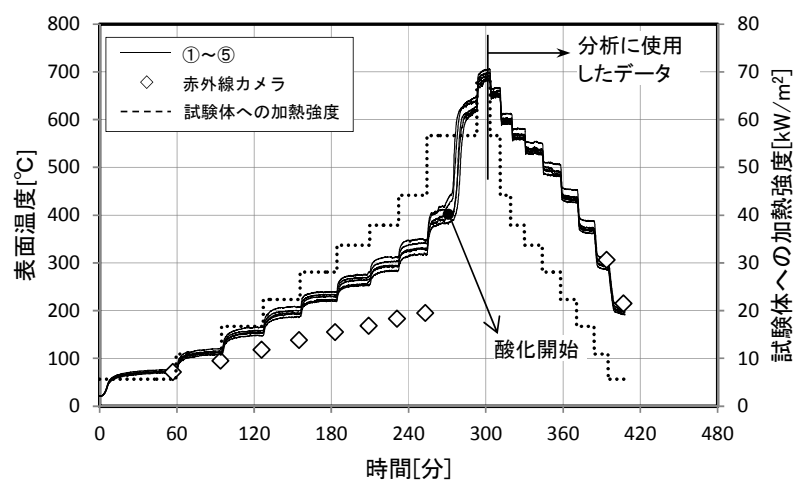

図 10 温度測定結果（鉛直設置）

（2）定常状態での温度分布

各加熱強度で温度が安定してから 5 分以上経過した後の測定值 (100 秒間) を平均し, 温度分布を検討した。一例として, 試験体一 の加熱強度が $28 \mathrm{~kW} / \mathrm{m}^{2}$ の測定点 1 5 で囲まれた範囲の温度分布を 図 11 に示す。試験体の設置方向によらず，試験体表面中心（測定点 1）の温度が最も高く，周囲（測定点 $2 \sim 5 ） に$ 向けて温度が低下して いる。中心と周囲の測定点の温度差の最大は, 水平設置で $24.8^{\circ} \mathrm{C}$, 鋁直設置で $24.6^{\circ} \mathrm{C}$ であり, 中心の温度上昇の $4.9 \%$ である。

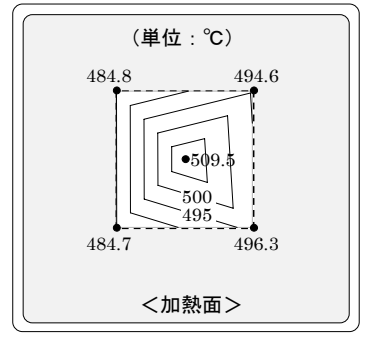

水平設置 (平面図)

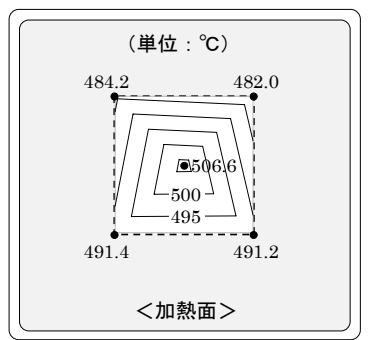

鉛直設置（正面図）
図 11 試験体への加熱強度 $28 \mathrm{~kW} / \mathrm{m}^{2}$ での温度分布（酸化後） 


\subsection{2 着火性試験の測定結果}

\section{(1) 測定結果}

試験体表面温度の測定結果を図 12 に示す。着火性試験装置の測定 では，あらかじめ表面を酸化させた試験体を使用したため, 試験体表 面中心とその周囲（測定点 2 5）の温度は CCM 試験の酸化後の值 に近い。酸化後の試験体を用いているが, 熱電対と赤外線カメラとの 温度差は大きい。着火性試験は CCM 試験よりもさらに試験体と赤外 線カメラとの角度が浅いため，誤差が大きくなったと考えられる。

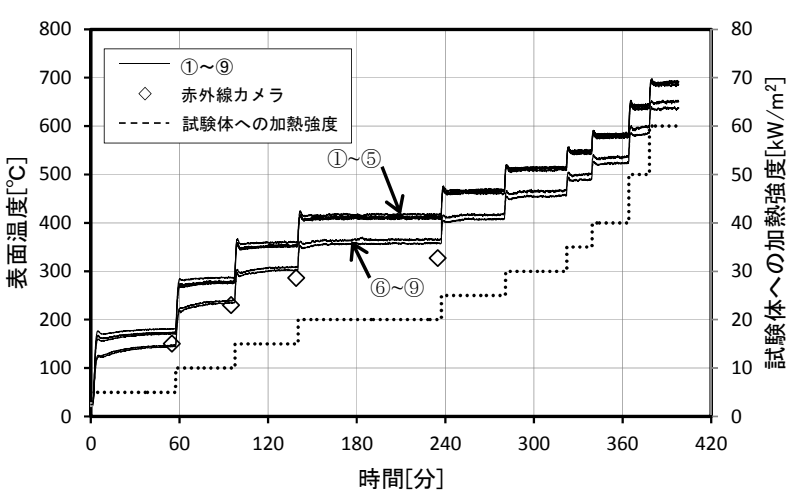

図 12 温度測定結果

（2）定常状態での温度分布

定常状態の表面温度は, CCM 試験と同様の方法で測定し, 平均し た。一例として, 試験体への加熱強度が $25 \mathrm{~kW} / \mathrm{m}^{2}$ の測定点 1 5 で 囲まれた範囲の温度分布図を図 13 に示寸。試験体表面中心（測定点 1）の温度が最も高く, 周囲（測定点 2 5）の温度はやや低い。中心 と周囲の測定点の温度差の最大は $8.3^{\circ} \mathrm{C}$ であり, 中心の温度上昇の $1.8 \%$ である。端部（測定点 6 9) との温度差の最大は $74.6^{\circ} \mathrm{C}$ であり, 大きな差が生じている。

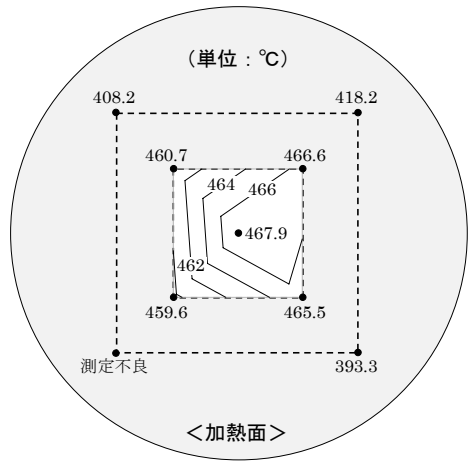

図 13 試験体への加熱強度 $25 \mathrm{~kW} / \mathrm{m}^{2}$ での温度分布（酸化後）

\section{4. 考察}

\section{1 加熱強度と表面温度との関係}

加熱強度と定常状態での表面温度の関係を図 14 および表 1 に示す。 ここで示寸表面温度は, 図 9, 10，12 の各加熱強度で定常状態とな った場合の中心（測定点 1) と周囲（測定点 $2 \sim 5$ ）の平均值とした。 ただし，CCM 試験では試験体が酸化する前の值は除外した。

各装置とも, 試験体への加熱強度が比較的小さい範囲では表面温度 の変化が大きいが, 加熱強度が大きくなるに従って変化は小さくなる。 $\mathrm{CCM}$ 試験装置で加熱強度が $40 \mathrm{~kW} / \mathrm{m}^{2}$ 以下の場合には, 試験体の
設置方向によらず表面温度は概ね同じであった。加熱強度が 40 $\mathrm{kW} / \mathrm{m}^{2}$ を超えると鉛直設置の方が徐々に低くなり，加熱強度 50 $\mathrm{kW} / \mathrm{m}^{2}$ では約 $8^{\circ} \mathrm{C}, 60 \mathrm{~kW} / \mathrm{m}^{2}$ では約 $20^{\circ} \mathrm{C}$ 低くなった。

着火性試験装置は，CCM 試験装置（水平設置）に比べて加熱強度 が $50 \mathrm{~kW} / \mathrm{m}^{2}$ 以上では表面温度が約 $20^{\circ} \mathrm{C}$ 低くなった。

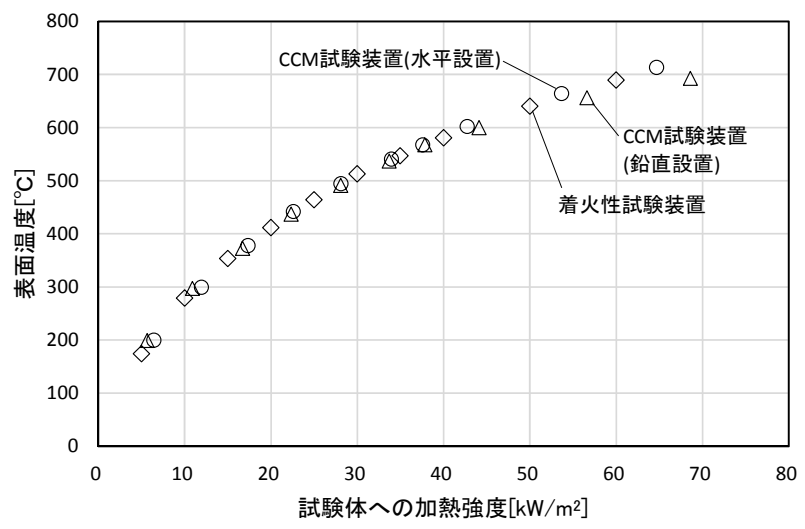

図 14 試験体への加熱強度と表面温度との関係

表 1 定常状態での試験体表面温度

\begin{tabular}{|c|c|c|c|c|c|c|}
\hline \multirow{2}{*}{$\begin{array}{l}\text { 校正時の } \\
\text { 加熱強度 } \\
\left(\mathrm{kW} / \mathrm{m}^{2}\right)\end{array}$} & \multicolumn{2}{|c|}{$\mathrm{CCM}$ (水平設置) } & \multicolumn{2}{|c|}{ CCM(鉛直設置) } & \multicolumn{2}{|c|}{ 着火性試験 } \\
\hline & 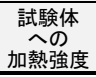 & $\begin{array}{c}\begin{array}{c}\text { 表面温度 } \\
\left({ }^{\circ} \mathrm{C}\right)\end{array} \\
\end{array}$ & 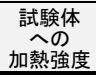 & $\begin{array}{c}\begin{array}{c}\text { 表面温度 } \\
\left({ }^{\circ} \mathrm{C}\right)\end{array} \\
\end{array}$ & 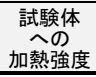 & $\begin{array}{c}\text { 表面温度 } \\
\left({ }^{\circ} \mathrm{C}\right) \\
\end{array}$ \\
\hline 5 & 6.4 & 199.6 & 5.7 & 198.7 & 5 & 173.8 \\
\hline 10 & 12.0 & 298.9 & 10.9 & 296.7 & 10 & 278.7 \\
\hline 15 & 17.4 & 377.4 & 16.8 & 372.0 & 15 & 353.1 \\
\hline 20 & 22.6 & 441.5 & 22.4 & 437.0 & 20 & 411.6 \\
\hline 25 & 28.1 & 494.0 & 28.1 & 491.1 & 25 & 464.1 \\
\hline 30 & 34.0 & 540.2 & 33.7 & 536.4 & 30 & 512.8 \\
\hline 35 & 37.6 & 567.4 & 37.9 & 567.4 & 35 & 546.5 \\
\hline 40 & 42.7 & 601.9 & 44.1 & 599.7 & 40 & 580.7 \\
\hline 50 & 53.7 & 663.7 & 56.6 & 656.0 & 50 & 640.2 \\
\hline 60 & 64.7 & 713.1 & 68.6 & 692.3 & 60 & 689.4 \\
\hline
\end{tabular}

\section{2 試験体表面の熱収支}

\subsection{1 熱収支の比較}

（1）試験体の向きによる比較（CCM 試験装置）

$\mathrm{CCM}$ 試験装置における試験体表面の熱収支を 2.2 節の方法で求め た結果を，水平設置の場合を図 15 に，鉛直設置の場合を図 16 に示 す。図 15 に示寸水平設置では伝導と対流の割合は小さく, 試験体一 の加熱強度が大きくなってもあまり増加しない。試験体一の加熱強度 が大きくなると再放射の割合が増え， $50 \mathrm{~kW} / \mathrm{m}^{2}$ では約 6 割となる。

図 16 に示寸鋁直設置の結果も水平設置と類似の傾向があるが，対 流が若干大きい。試験体への加熱強度が $40 \mathrm{~kW} / \mathrm{m}^{2}$ を超えるとその差 が明らかになる。鉛直設置では試験体表面に沿って上方へ流れる気流 が強くなるためと考えられる。伝導は水平設置と同様に小さい。

（2） CCM 試験装置（水平設置）と着火性試験装置との比較

着火性試験装置における材料表面の熱収支を図 17 に示寸。再放射 が最も大きいことは CCM 試験装置と同じであるが, 対流が小さかっ た。着火性試験装置は CCM 試験装置に比べて試験体寸法が大きく, さらに試験体周囲の固定プレートなどが気流を妨げているためと考 えられる。一方, 裏打ち材が薄いので伝導は CCM 試験装置の約 6 倍 であった。 


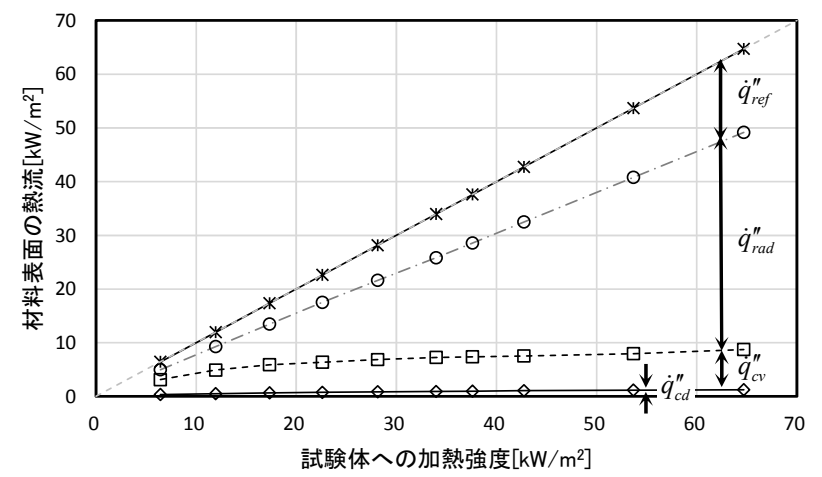

図 15 材料表面の熱収支 (CCM 試験装置, 水平設置)

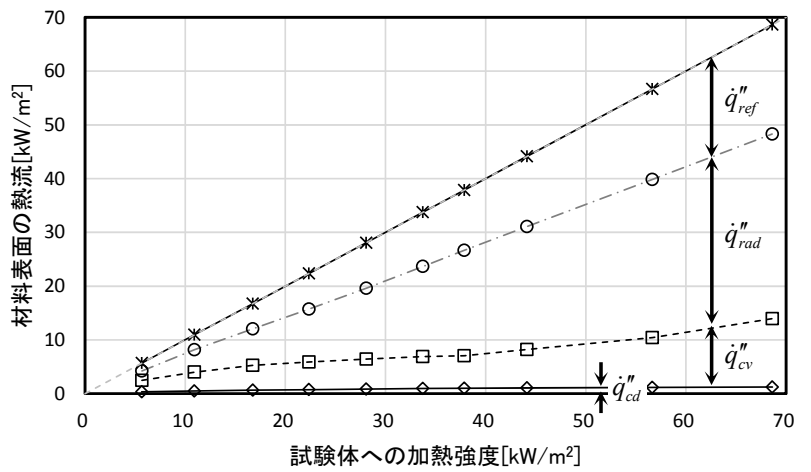

図 16 材料表面の熱収支 (CCM 試験装置, 鉛直設置)

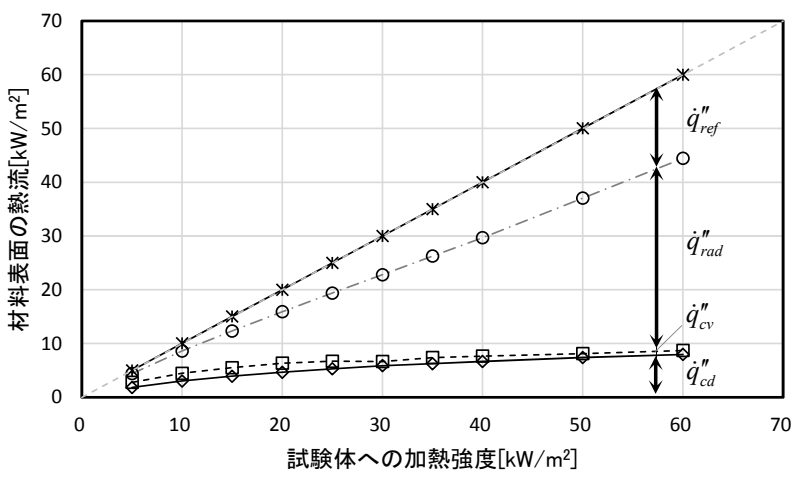

図 17 材料表面の熱収支 (着火性試験装置)

\subsection{2 対流熱伝達率の比較}

図 15〜17の対流熱流と表 1 の表面温度を式(4)に用いて求めた対流 熱伝達率を図 18 に示す。CCM 試験装置の対流熱伝達率は, 表面温 度が $200 \sim 400^{\circ} \mathrm{C}$ 範囲において水平設置で約 $15 \mathrm{~W} /\left(\mathrm{m}^{2} ・ \mathrm{~K}\right)$, 鉛直設 置で約 $13 \mathrm{~W} /\left(\mathrm{m}^{2} \cdot \mathrm{K}\right)$ であった。表面温度が $600^{\circ} \mathrm{C}$ 以上では鉛直設置が 急激に大きくなる。着火性試験装置の対流熱伝達率は, 表面温度が $200 \sim 400^{\circ} \mathrm{C}$ 範囲では $\mathrm{CCM}$ 試験装置 (水平設置) の約 $1 / 3$ となり,

約 $6 \mathrm{~W} /\left(\mathrm{m}^{2} \cdot \mathrm{K}\right)$ であった。

図 18 には CCM 試験装置（水平設置）における既往の研究結果を 併せて示している。 Staggs $^{8), 9)}$ は, 放射率が $0.79 \sim 0.94$ の鋼板を用 いて本研究と同様に表面温度を測定し, 表面の熱収支から対流熱伝達 率を求めている。裏打ち材のセラミックファイバーが $25 \mathrm{~mm}$ と本研 究よりも薄いことや, 表面温度の変化を指数関数で近似した時の漸近 温度を定常温度と見なしたこと等のためか, 表面温度が本研究の測定
值よりも低い值となっている。さらに，式(1)の熱収支式において伝 導を無視している。その結果, 対流熱伝達率は本研究よりも大きな值 となっている。

Dietenberger ${ }^{10)}$ は, 乾式ボードで校正実験を行い, 対流熱伝達率 を次式で表している注3)。

$h_{c}=0.01433+1.33 \times 10^{-4} \dot{q}_{e}^{\prime \prime}$

Dietenberger の分析でも材料内部への熱伝導を無視しており，その ため本研究よりも大きな值となっている。Zhang ら ${ }^{11)}$ は熱回路網か らパラメータの逆解析を行い, 試験体表面の対流熱伝達率を実験結果 から推定している。その結果は本研究の測定值より小さい。

図 18 の破線は，水平平板を上面から加熱したときの対流熱伝達率 の実験式である ${ }^{12)}$ 。

$N_{u}=0.14\left(G_{r} P_{r}\right)^{1 / 3}$

この值は，表面温度が $200 \sim 600^{\circ} \mathrm{C}$ 範囲では約 $9 \sim 11 \mathrm{~W} /\left(\mathrm{m}^{2} \cdot \mathrm{K}\right)$ の 範囲であり，本研究の測定值より小さい。

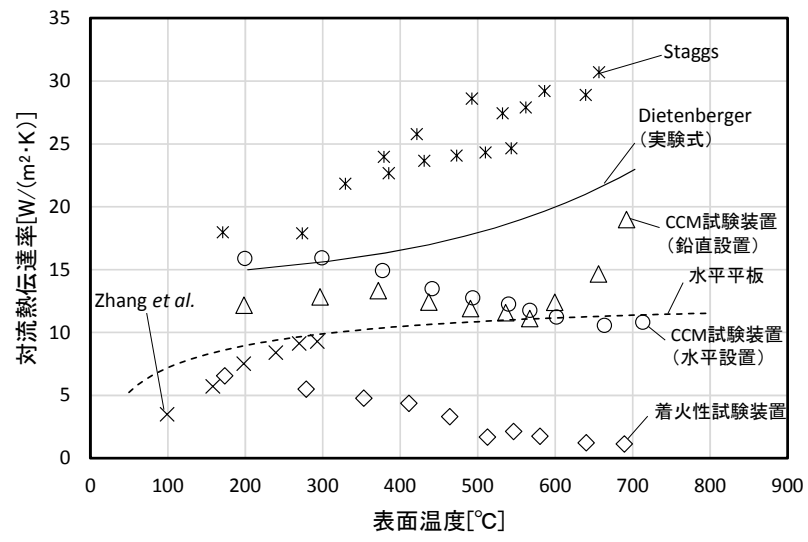

図 18 試験体表面の対流熱伝達率

\subsection{3 みかけの対流熱伝達率}

前項で述べたように，伝導を無視した熱収支式を用いると，対流熱 伝達率を過大に推定することとなる。式(1)～式(5)を変形すると次式 となり、伝導を無視して得られる值は本来の対流熱伝達率に加熱側表 面から試験体下部の空気までの間の熱貫流率を加えた值 $h_{c}+K$ となる。 これをみかけの対流熱伝達率と呼ぶ。

$h_{c}+K=\frac{1}{T_{s}-T_{\infty}}\left\{\varepsilon \dot{q}_{e}^{\prime \prime}-\varepsilon \sigma\left(T_{s}^{4}-T_{\infty}^{4}\right)\right\}$

図 18 に示した対流熱伝達率に熱貫流率を加えた值を図 19 に示す。 CCM 試験装置では裏打ち材を厚くできるので，みかけの対流熱伝達 率は本来の対流熱伝達率と大差ない。着火性試験装置では裏打ち材が 薄いので, 見かけの対流熱伝達率は本来の值に比べて大きく, 表面温 度が $200 \sim 400^{\circ} \mathrm{C}$ 範囲では約 3 倍となる。着火性試験で薄い材料を 試験する場合には, 裏面への熱伝導による熱損失の影響が無視できな い。 


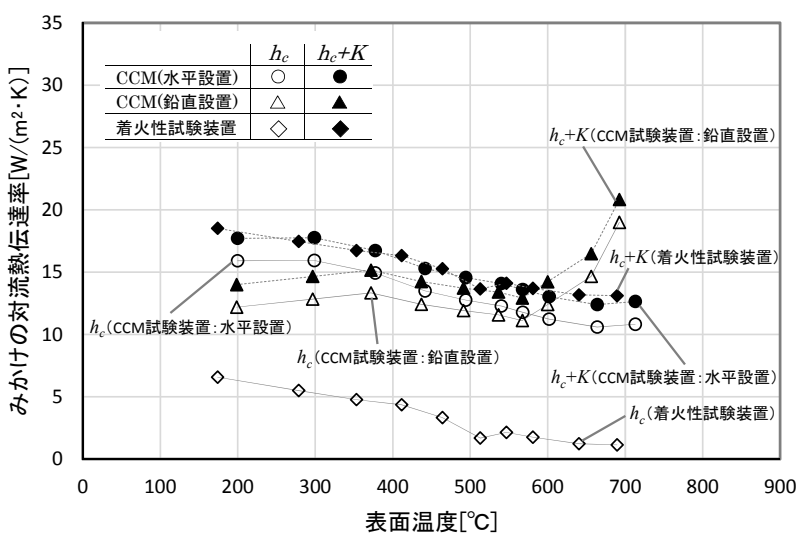

図 19 表面温度とみかけの対流熱伝達率の関係

\section{5. 結論}

$\mathrm{CCM}$ 試験装置と着火性試験装置について, 種々の加熱強度で定常 状態での試験体（亜鉛めっき鋼板）表面温度を測定し, 表面の熱伝達 を調べた。CCM 試験装置については, 試験体の設置方向による違い を比較した。着火性試験装置では, 水平設置の CCM 試験と比較した。 その結果，以下の結論を得た。

1） いずれの装置でも再放射が大きな割合を占め，加熱強度が大き いほど再放射の比率は増加する。対流と伝導の割合は小さい。

2） CCM 試験装置では, 水平設置と鉛直設置で熱伝達に大きな違 いは見られない。ただし, 表面温度が $600^{\circ} \mathrm{C}$ 以上になると, 鉛 直設置では対流が増加する。

3）着火性試験装置と水平設置の CCM 試験を比べると, 着火性試 験装置では対流が少なく, 裏面への伝導が大きい。裏打ち材の 熱貫流率が大きいことが熱損失の原因である。

4）表面温度が $200 \sim 400^{\circ} \mathrm{C}$ における対流熱伝達率は，CCM 試験装 置で $13 \sim 15 \mathrm{~W} /\left(\mathrm{m}^{2} \cdot \mathrm{K}\right)$ 程度, 着火性試験装置で $6 \mathrm{~W} /\left(\mathrm{m}^{2} \cdot \mathrm{K}\right)$ 程 度と推定される。裏面への熱貫流率を加えたみかけの対流熱伝 達率は, 裏打ち材の厚い $\mathrm{CCM}$ 試験装置では本来の対流熱伝達 率と大差ないが，着火性試験装置では差が大きくなる。

\section{6. 今後の課題}

本研究により、着火性試験装置および CCM 試験装置における材料 の加熱条件を明確化した。今後はこの結果を用いて試験結果の相互比 較や内装材料の燃え拡がりモデル 2)への入力データ整備方法等を検 討する所存である。

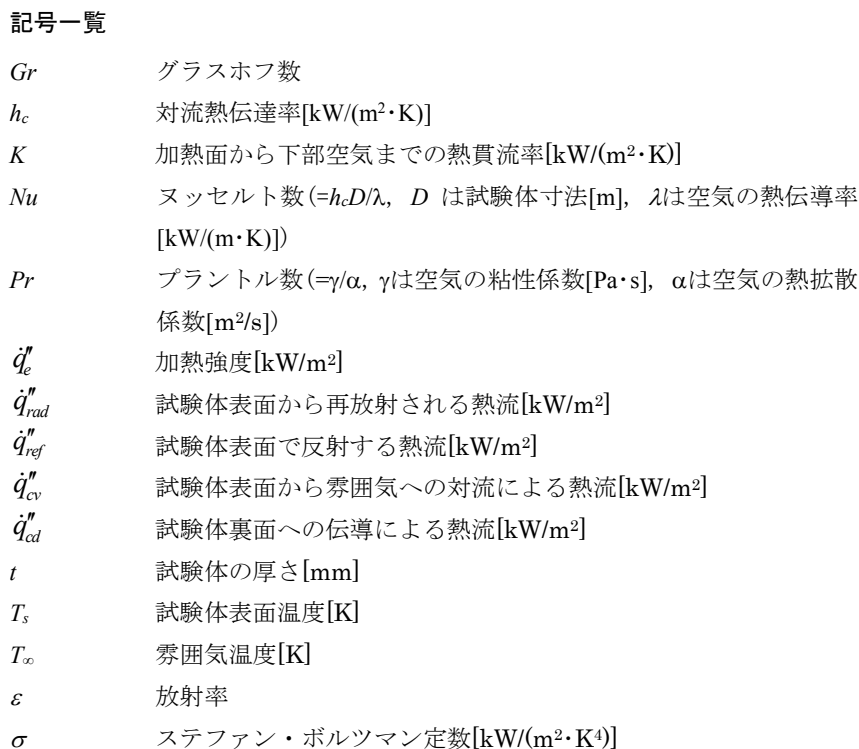

注

\section{注 1）試験体表面の放射率}

試験体表面の放射率は，加熱した状態で定常状態となったときの試験体表 面の温度を, 熱電対と赤外線カメラ（視野分解能 : $1.8 \mathrm{~mm} / 1 \mathrm{~m}$, 測定レンジ $0 \sim 1500^{\circ} \mathrm{C}$ ，最小検知温度差 $0.04^{\circ} \mathrm{C}$ ，測定精度 $\pm 2 \%$ ) で測定し，式(A1)によ り求めた。

$\varepsilon=\frac{T_{I R}^{4}-T_{\infty}^{4}}{T_{s}^{4}-T_{\infty}^{4}}$

ただし， $T_{I R}$ は放射率を 1.0 に設定した赤外線カメラの指示值 $[\mathrm{K}] ， T_{s}$ は熱電 対による表面温度測定值[K]である。各実験条件とも試験後の試験体を用い た。赤外線カメラの撮影は試験体表面の斜め上方から行い，試験体表面との 角度を深くとるため試験体表面と電熱ヒータ間の距離を約 $80 \mathrm{~mm}$ とした。

測定結果を図 $\mathrm{A} 1$ に示寸。 4.2 節の熱収支の計算においては，放射率と表 面温度との関係を 2 次曲線で近似して用いた。

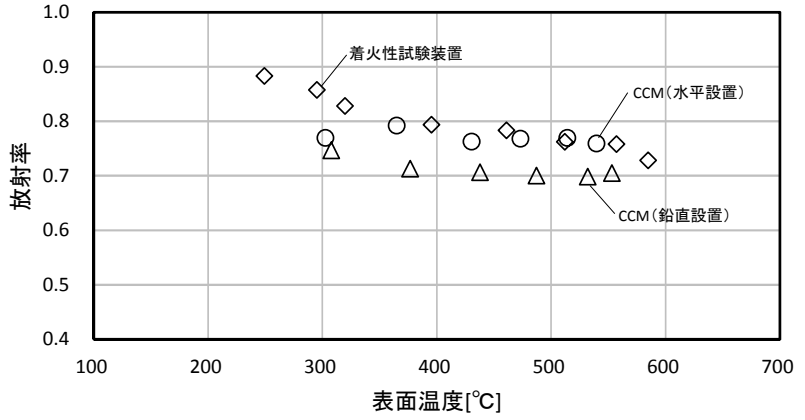

図 A1＼cjkstart試験体表面温度と放射率の関係

注 2）試験体への加熱強度

2.1 節で述べたように, CCM 試験の加熱強度の設定では, 試験体表面の中 央位置に熱流束計を単独で設置して入射熱流束を測定している。しかし，試 験体を設置した状態では、試験体表面と電熱ヒータ表面との間の相互反射に より試験体表面への入射熱流束が増加する。そこで，大きさ $100 \times 100 \mathrm{~mm}$, 厚さ $50 \mathrm{~mm}$ のセラミックボードに熱流束計を埋め込み，その上にリテイナ ーフレームを被せた状態で試験体への入射熱流束を測定した。熱流束計の設 置位置は，図 5 に示寸温度測定位置と同じ位置とした。加熱強度は 3.1.1 と 同様に校正時の加熱強度で設定した。測定は水平設置と鉛直設置のそれぞれ で行った。

校正時の加熱強度と試験体への加熱強度との比較を図 B1 に示す。ここで は Lukas ${ }^{13)}$ の測定結果も併せて示す。試験体への加熱強度は, 校正時の加熱 強度に比心゙て約 $10 \%$ 大きい。加熱強度 $40 \mathrm{~kW} / \mathrm{m}^{2}$ 以下における試験体への加 熱強度と校正時の加熱強度の関係は，試験体の設置向きによる影響は少ない。 


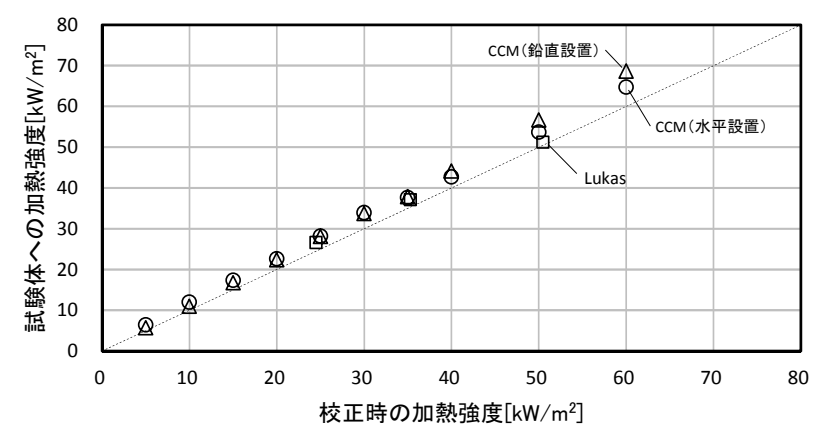

図 B1＼cjkstart校正時の加熱強度と試験体への加熱強度との比較

注 3) Dietenberger の実験式の解勫

文献 10)においては, 加熱強度が $50 \mathrm{~kW} / \mathrm{m}^{2}$ のときの表面温度が定常状態 で約 $600^{\circ} \mathrm{C}$ なったことが示されている。式(1)で熱伝導を無視し，これらの 值を代入して試験体表面の放射率を逆算すると 0.69 となった。逆算した放 射率を式(1)に用いて表面温度と対流熱伝達率の関係を求め, 図 18 に示した。

\section{参考文献}

1) International Organization for Standardization, ISO5657:1997, Reaction to fire tests - Ignitability of building products using a radiant heat source, 1997

2）建設省大臣官房技術調査室，建設省総合技術開発プロジェクト 防・耐火 性能評価技術の開発報告書, 1998

3) International Organization for Standardization, ISO5660-1:2002, Reaction to fire tests - Heat release, smoke production and mass loss rate, Part1: Heat release rate (cone calorimeter method), 2002

4) Babrauskas V. : Ignitability measurements with the cone calorimeter, Fire and materials, Vol.11, pp.31-43, 1987

5) Shiels T.J. : The effect of geometry and ignition mode on ignition times obtained using cone calorimeter and ISO ignitability apparatus, Fire and materials, Vol.17, pp.25-32, 1993

6) Tata J. : Optimization of the procedure to burn textile fabrics by cone calorimeter: Part I Combustion behavior of polyester, Fire and materials, Vol.35, pp.397-409, 2011

7) American Society for Testing Materials, ASTM E 1321 Standard test method for determining material ignition and flame spread properties, 2002

8) Staggs J.E.J., H.N. Phylaktou : The effects of emissivity on the performance of steel in furnace tests, Fire Safety Journal, 43(1), pp.1-10, 2008

9) Staggs J.E.J. : Convection heat transfer in the cone calorimeter, Fire Safety Journal, 44, pp.469-474, 2009

10) Dietenberger M. : Ignitability analysis using the cone calorimeter and LIFT apparatus, in: proceeding of the International Conference on Fire Safety, vol.22, 1996

11) Zhang J. : Determination of the convective heat transfer coefficient in three-dimensional inverse heat conduction problems, Fire Safety Journal, 44, pp.681-690, 2009

12) Burmeister, L.C. : Convective Heat transfer, John Wiley \& Sons, 1983

13) Lukas,C. : Measurement of heat flux in the cone calorimeter, Fire and Materials, Vol.19, pp.97-98, 1995 


\title{
SPECIMEN SURFACE HEAT TRANSFER IN CONE CALORIMETER AND IGNITABILITY TEST APPARATUS
}

\author{
Tsuneto TSUCHIHASHI* and Kazunori HARADA** \\ * Fire Engineering Lab, Environment Dept., General Building Research Corporation of Japan \\ ** Prof., Graduate School of Engineering, Kyoto Univ., Dr. Eng.
}

The ignitability of materials had been measured by ISO 5657 ignitability test apparatus as far. On the other hand, ISO 5660 cone calorimeter (CCM) test is getting popular for measuring heat release rate and ignition time. However, the ignition time measured would be influenced by the rate of surface temperature rise due to the difference in heat transfer characteristics of testing apparatus as pointed out qualitatively by previous researchers. One of the differences is the backing board, which alter the conduction heat loss toward rear surface. The other factor could be the size and orientation of specimen. The specimen size is larger in ignitability test apparatus than in CCM. The difference of specimen size may alter the convection heat loss from specimen surface. In addition, CCM is capable to heat a specimen in horizontal and vertical orientation. The difference in orientation also alters convective heat loss from surface.

In this study, galvanized thin steel plate $(0.27 \mathrm{~mm})$ was heated by CCM in horizontal and vertical orientation and by ignitability test apparatus in horizontal orientation. The backing board was ceramic fiber blanket (50mm) for CCM calcium silicate board $(6 \mathrm{~mm})$ for ignitibility test apparatus. To measure the steady state surface temperature, type $\mathrm{K}$ thermocouples were welded to specimen's surface. Heating intensity was in the range of 5 to $68 \mathrm{~kW} / \mathrm{m}^{2}$. The corresponding surface temperature were 174 to $713^{\circ} \mathrm{C}$.

The surface temperatures at steady state were almost similar in CCM in horizontal and vertical orientations when the heating intensity was below $40 \mathrm{~kW} / \mathrm{m}^{2}$. At above $40 \mathrm{~kW} / \mathrm{m}^{2}$, surface temperature was slightly lower in vertical orientation test than in horizontal orientation test. The surface temperatures in ignitability test apparatus were lower than that in horizontal CCM by about $20^{\circ} \mathrm{C}$ for heating intensities over $50 \mathrm{~kW} / \mathrm{m}^{2}$.

The specimen's surface heat balance was estimated by measured surface temperatures. In all the results, re-radiation dominated the heat loss from surface. Convection and conduction heat loss are relatively small. In comparison of horizontal and vertical CCM results, there were no obvious differences when the heating intensity is below $40 \mathrm{~kW} / \mathrm{m}^{2}$. At above $40 \mathrm{~kW} / \mathrm{m}^{2}$, when the surface temperature is higher than $600^{\circ} \mathrm{C}$, the convection heat loss was larger in vertical CCM than in horizontal CCM. In case of ignitability test apparatus, convection heat loss is smaller than that in horizontal CCM, but the conduction heat loss was about six times as much.

The convective heat transfer coefficient was estimated by using the calculated heat flux. The coefficient was around $0.013-0.015 \mathrm{~kW} /\left(\mathrm{m}^{2} \cdot \mathrm{K}\right)$ in $\mathrm{CCM}$ for the surface temperature range of 200 to $400^{\circ} \mathrm{C}$ for horizontal and vertical orientations. The value is larger than the conventional experimental formula for heated horizontal plate. Above $600^{\circ} \mathrm{C}$, the coefficient tends to increase in vertical CCM. On the other hand, the convective heat transfer coefficient in ignitability test apparatus is about $0.006 \mathrm{~kW} /\left(\mathrm{m}^{2} \cdot \mathrm{K}\right)$, which is about half to one third of the values in CCM.

The effect of backing board was analyzed by neglecting the conduction heat loss in surface heat balance equation. As results, apparent convective heat transfer coefficient was estimated. The apparent values for the surface temperature range of 200 to $400^{\circ} \mathrm{C}$ were close to intrinsic values in $\mathrm{CCM}$, but three times larger in ignitability test apparatus. It was suggested that the effect of conduction heat loss to rear surface in ignitability test apparatus are not negligible in case of thermally thin specimens. 